\section{Perbuatan Melawan Hukum Menguasai Tanah Hak Milik Orang Lain \\ (Studi Putusan Mahkamah Agung Nomor $3302 \mathrm{~K} / \mathrm{Pdt} / 2018$ )}

Oleh:

\section{Faisal Rahendra Lubis, Dikka Aprilya}

\section{E-mail: faisal.rahendra@fh.uisu.ac.id dikkaaprilya@gmail.com}

\section{Abstrak}

Perbuatan melawan hukum merupakan suatu perbuatan yang dapat merugikan hak-hak orang lain yang diciptakakan oleh hukum. Hal ini menunjukkan bahwa perbuatan melawan hukum semata-mata berasal dari Undang-Undang, bukan karena perjanjian yang berdasarkan persetujuan dan perbuatan melawan hukum akibat perbuatan manusia yang ditentukan sendiri oleh Undang-Undang. Berdasarkan hasil penelitian bahwa suatu perbuatan dapat dikatakan melawan hukum apabila telah melengkapi beberapa unsur yaitu adanya suatu perbuatan, perbuatan itu harus melawan hukum, perbuatan itu harus menimbulkan kerugian, perbuatan itu dilakukan dengan kesalahan, dan antara perbuatan dan kerugian yang ditimbulkan harus ada hubungan kausal. Perbuatan melawan hukum didalam kasus ini dengan telah melanggar peraturan perundang-undangan dalam Pasal 1335 dan Pasal 1337 KUHPerdata, yaitu suatu sebab terlarang dan adanya hal atau materi perjanjian yang bertentangan dengan Undang-Undang sehingga suatu perbuatan tersebut dapat dikenakan Pasal 1365 KUHPerdata.Disimpulkan bahwa unsur dari perbuatan melawan hukum adalah adanya perbuatan yang melawan hukum yang dilakukan oleh pelaku dan perbuatan tersebut bertentangan dengan hak orang lain yaitu menguasai tanah hak milik yang bukan miliknya. Akibat hukum apabila seseorang menguasai tanah hak milik orang lain maka orang yang menguasai tanah hak milik orang lain tersebut harus mengosongkan/meninggalkan tanah hak milik dan mengembalikan tanah hak milik tersebut kepada pemiliknya.
Segala bentuk perbuatan yang dikategorikan melawan hukum ketika perbuatan itu bertentangan dengan hukum, dan apabila seseorang telah melakukan kesalahan dengan dapat merugikan hak orang lain.

Kata Kunci: Perbuatan Melawan Hukum, Akibat Hukum, Tanah Hak Milik

\section{Abstract}

Unlawful deed are an adverse effect to the rights of other people created by the law. This indicates that unlawful deed of disobedience based on consent and legal actions resulting from man's own actions. Studies suggest that an act is unlawful when it adds to the several elements of an act, it must unlawful deed, it must inflict harm, it is wrong, and between the act and the harm inflicted there must be a causal relationship. Unlawful deed in this case by violating the ordinance in article 1335 dan article 1337 KUHPerdata, that is a forbidden cause and the existence of covenant matters or materials in violation of the law make it subject to article 1365 KUHPerdata. It was concluded that elements of unlawful deed constituted unlawful deed performed by the individual and those works were contrary to the right of another person to possession of property that didn't belong to him. As a result when a man takes possession of the land of another's property, the owner of the land of another's property is required to vacate and return the land of property rights to its owner. All forms of deeds are categorized unlawful deed when they are unlawful deed, and when an individual has done wrong at the expense of the rights of another.

Keywords: Unlawful Deeds, Legal
Consequences, Land Of Proferty

\section{I.PENDAHULUAN}

\section{A. LatarBelakang}

Perkembangan kehidupan pada belakangan ini dapat kita lihat disekitar kita bahwa masih banyak orang-orang yang melakukan pelanggaran hak-hak atas hak orang lain, yang mana diketahui salah satunya yang menjadi objek terhadap kepemilikan atas suatu 
Media Komunikasi dan Informasi Hukum dan Masyarakat

tanah atau pun perkarangan yang di miliki seseorang untuk dikuasai menjadi hak miliknya pribadi. Tanah sebagai salah satu sumber kekayaan alam memiliki hubungan erat sekali dengan kelangsungan kehidupan manusia. Dalam terminology asing tanah disebut dengan land, soil (Inggris). Manusia dalam kehidupannya senantiasa berhubungan dengan tanah. Antara manusia dan tanah merupakan salah satu hal yang tidakdapatdipisahkan. untukmemenuhi kebutuhan hidupnya seperti kebutuhan tempat tinggal/rumah, tempat melakukan kegiatan pertanian sebagai sumber pangan sehari-hari bahkan tempat akhir hanyat seseorang ketika sudah tidak bernyawa lagi (mati), manusia sangat erat dan selalu berhubungan dengan tanah.

Menurut Muhamad Yamin Lubis, et.al dalambukunya Hukum Agraria Lanjutan mengatakan bahwa:

Ketentuan yuridis yang mengaturmengenaieksistensitanahyaituterda patdalamUndang-UndangNomor 5 Tahun 1960 tentangPeraturan Dasar PokokPokokAgraria (selanjutnyadisebut UUPA), yang

merupakanpelaksanaandariketentuanPasal

33 ayat (3) Undang-Undang Dasar 1945 yang menyatakanbahwabumi dan air dan kekayaanalam yang terkandung di dalamnyadikuasai oleh negara dan dipergunakanuntuksebesar-

besarnyakemakmuranrakyat. ${ }^{1}$

Dalamkamusbesar Bahasa Indonesia disebutkanpengertiantanah,

yaitupermukaanbumiataulapisanbumi yang diatas sekali. Pengertian tanah diatur dalam UUPA terdapat dalam Pasal 4 ayat (1) yaitu bahwa atas dasar hak menguasai dari negara sebagai yang dimaksud dalam Pasal 2 ditentukan adanya macam-

${ }^{1}$ Muhammad YaminLubis, et al, Hukum AgrariaLanjutan, USU Press, Medan, 2019, h.2. macamhakatastanahpermukaanbumi, yang disebuttanah, yang dapatdiberikankepada dan dipunyai oleh orang-orang, baiksendirisendirimaupunbersama-sama orang lain serta badan-badan hukum. Dengan demikian maksud tanah dalam pasal ini adalah permukaan bumi.

Manusia selalu berusaha untuk dapat memiliki dan menguasai tanah, karena tanah penting untuk kehidupan. Dimana kebutuhan manusia akan tanah selalu bertambah, dan ketersediaan akan tanah terbatas. "Dengan adanya kebutuhan akan tanah sehingga Negara Republik Indonesia, memberikanjaminan dan memberikan perlindungan atas hak-hak warga Negara tersebut untuk mendapatkan, mempunyai, dan menikmati hak milik atas tanah". 2

"Hak atas tanah adalahh ak yang member wewenang kepada yang mempunyai hak untuk menggunakan atau mengambil manfaat dari tanah yang di hakinya. Kata menggunakan mengandung pengertian bahwa hak atas tanah digunakan untuk kepentingan mendirikan bangunan, misalnya rumah, toko, hotel, kantor, pabrik". 3

Ketentuantentanghak-hak atas tanah diatur di dalamPasal 16 ayat (1) UUPA yang menyatakanbahwa "hak-hak atas tanah sebagai yang dimaksud dalam Pasal 4 ayat (1) ialah:

a. Hakmilik;

b. Hakgunausaha;

c. Hakgunabangunan;

d. Hakpakai;

e. Haksewa;

f. Hakmembukatanah;

g. Hakmemunguthasilhutan;

h. Hak-hak lain yang tidaktermasukdalamhak-haktersebut di atas yang akanditetapkandenganUndangUndangsertahak-hak

yang

¿UripSantosa, Hukum Agraria dan

Hak-Hak Atas Tanah, Prenadamedia Group, Jakarta, 2010, h.87.

UUripSantosa, Pendaftaran dan PeralihanHak Atas Tanah, Prenadamedia Group, Jakarta, 2010, h.49. 
Media Komunikasi dan Informasi Hukum dan Masyarakat

sifatnyasementarasebagai disebutkandalamPasal 53.

HakmilikatastanahdiaturdalamPasal 20-

27 UUPA. Pengertian hak milik menurut ketentuan Pasal 20 ayat (1) UUPA adalah hak turun-temurun, terkuat, dan terpenuh yang dapat dimiliki oleh seseorang atas tanah, dengan tetap memperhatikan bahwa semua hak atas tanah mempunyai fungsi sosial sehingga tidak mengganggu kepentingan umum atau orang lain. Pada Pasal 20 ayat (2) UUPA dijelaskan bahwah

akmilikatastanahdapatdialihkan. Pengalihan hak atas tanah merupakan suatu perbuatan hukum yang bertujuan untuk memindahkan hak dari satu pihak kepihak lain. Salah satu contoh hak atas tanah yang dapat dialihkan melalui pewarisan tanah adalah hakmilik.

"Hak milik sebagai hak yang terkuat dibandingkan dengan hak atas tanah lainnya berarti hak milik tidak mudah dihapus dan lebih mudah dipertahankan terhadap ganguan dari pihak lain". ${ }^{4}$

"Tanah memilikiperan yang sangatpenting, begitupentingnyatanahbagikehidupanmanu siasehinggatidakmengherankanapabilaseti apmanusiainginmemilikiataumenguasainya yang berakibattimbulnyamasalahmasalahpertanahan yang kerap kali dapatmenimbulkanperselisihan". ${ }^{5}$

Perselisihantanah

yang

seringterjadiadalahseseorangmenguasaitanahh akmilik orang

lain.

Masalahmenguasaitanahbukanlahsuatuhal yang baruterjadi di Indonesia. Kata menguasaidapatdiartikandenganperbuatanmeng uasaihakatauhartadengansewenangwenangataudengantidakmengindahkanhukum

${ }^{4}$ Adrian Sutedi, Peralihan Hak Atas

Tanah dan Pendaftarannyal, Sinar Grafika, Jakarta, 2018, h.60-61.

${ }^{5}$ Rusmadi

Murad, dan

aturan

Perbuatan

yang

bertentangandenganhak orang lain (inbreuk op eensandersrecht) termasuk salah satuperbuatan yang dilarang oleh Pasal 1365 KUHPerdata. Hak-hak yang dilanggaradalahhakhakseseorang yang diakui oleh hukum.Tindakan menguasaitanahsecaratidaksahdenganmelangg arhak orang lain adalahsuatuperbuatan yang melawanhukum.

Perbuatanmelawanhukumdiaturdalam

Kitab Undang-Undang Hukum Perdata dalam Pasal 1365-1380 KUHPerdata, termasuk kedalam perikatan yang timbul dari UndangUndang. Pada Pasal 1365 KUHPerdata berbunyi: "tiap perbuatan melanggar hukum, yang membawa kerugian kepada orang lain mewajibkan orang yang karena salahnya menerbitkan kerugianitu, mengganti kerugian tersebut".

Perbuatan melawa nhukum yang dimaksud dalam Pasal 1365 KUHPerdata bias menjerat orang-orang yang melakukan penguasaan terhadap tanah milik orang lain. Penguasaan tanah ini terjadi dikarenakan dalam penyerahan dan kepemilikan Sertifikat Hak Milik (SHM) dilakukan dengan melanggar peraturan perundang-undangan dimana melanggar peraturan perundang-undangan adalah suatu perbuatan melawa nhukum.

Menguasai tanah milik orang lain akanmerugikanpihak yang memiliki tanah dan pihak yang memiliki tanah bias meminta ganti rugi atas kerugian yang dialaminya. Menguasai hak atas tanah milik orang lain tanpapersetujuan orang yang memiliki tanah adalah suatu perbuatan melawan hukum yang mana seseorang secara tanpa hak masuk ketanah milik orang lain atau menyebabkan seseorang/orang lain atau benda tertentutetaptinggal di tanahmilik orang lain. 
Media Komunikasi dan Informasi Hukum dan Masyarakat

Perbuatan melawan hukum terhadap hak milik atas tanah dalam hukum agrarian disebut atau dikenal dengan sengketa tanah. Menyangkut ha Itersebut terdapat suatu perkara sengketa tanah yang terjadi di Kota Kotamobagu, Propinsi Sulawesi Utara. Perkara ini awalnya hanya di Pengadilan Negeri Kotamobagukemudian naik ketingkat Banding di Pengadilan Tinggi Manado dan akhirnya tingkat Kasasi di Mahkamah Agung Republik Indonesia. Pada kasus ini Pemohon Kasasi menggugat Termohon Kasasi yang mana Termohon Kasasi adalah mantanistri dari Pemohon Kasasi. Dimana Pemohon Kasasi menggugat Termohon Kasasi karena Termohon kasasi telah menguasai tanah objeksengketa dan SHM Nomor 27/ Modayag atas nama Dorti Kapoh secara melawa nhukum.

Pihak yang berperkara dalam kasus ini adalah Decky Posumah Kapoh sebagai Pemohon Kasasi, Lenny Kanter sebagai Termohon Kasasi dan Badan Pertahanan Nasional Pusat Di Jakarta C.q. Kantor Wilayah Badan Pertanahan Nasional Propinsi Sulawesi Utara C.q. Badan Pertanahan Nasional KabupatenBolaangMongondowsebagaiTurutTer mohonKasasi.

Bahwa Pemohon Kasasi adalah pemilik atas sebidang tanah dan rumah di Desa Tobongan, Kecamatan Modayag, Kabupaten Bolaang Mongondow Timur. la mendapatkan tanah tersebut setelah kedua orang tuanya meninggal dunia. Setelah orang tuanya meningal dunia dan meninggalkan sebidang tanah dan rumah, atas kesepakatan bersama antara anak-anakdari orang tuanya (ayah alm. Chung Ping Foe dan Ibu almh. DortjiKapoh) makatanah dan rumahbersertifikatHak Milik Nomor
27/ModayagatasnamaDortjiKapohtelahmenjadi milikPemohonKasasi (DeckyPosumahKapoh).

PemohonKasasipernahmenikahdengan

TermohonKasasinamunkemudianmerekabercer aisesuaidenganPutusanPengadilan Negeri Kotamobagutertanggal 17 Desember 2015 No.114/Pdt.G.2015/PN.Ktg. Setelah merekaberceraiTemohonKasasimenguasaitana hdengan SHM No. 27/Modayag dan TermohonKasasitidakmaumenyerahkanSertifika tHak Milik tersebutkepadaPemohonKasasisebagaiahliwari ssahdari orang tuanya. Hal iniyang menyebabkanPemohonKasasimenggugatTermo honKasasi. PemohonKasasimeminta agar tanahnyadikembalikan dan Termohon Kasasi menyerahkan SHM No. 27/ModayagkepadaPemohonKasasi.

Pada putusanMahkamah Agung No. $3302 \mathrm{~K} / \mathrm{Pdt} / 2018$ telah terjadi adanya perbuatan melawan hukum yang dilakukan oleh Termohon Kasasi. Dalam hal ini dapat dilihat bahwa Pemohon Kasasi yang merupakan pemilik tanah, yang menjadiobjeksengketatersebut dan Termohon Kasasi hanyalah mantan isteri dari PemohonKasasi yang telahmenempati dan menguasai tanah tersebut yang sudah jelas bahwa tanah yang dikuasainya adalah milik dari Pemohon Kasasi.

Bahwa oleh karena Termohon Kasasi menguasai dan menempati tanah dan bangunan milik orang lain secara tidak sah dan tanpa hak adalah suatu perbuatan melawan hukum yang telah diatur dalam Pasal 1365. Perbuatan Termohon Kasasi secara langsung menimbulkan kerugian materiil dan inmaterial terhadap Pemohon Kasasi, oleh karena itu sebagaimana diatur dan ditentukan dalam Pasal 1365 KUHPerdata Pemohon Kasasi sebagai pihak yang dirugikan berhak mengajukan 
Media Komunikasi dan Informasi Hukum dan Masyarakat

tuntutan kerugian dan mendapatkan haknya kembali atas tanah tersebut.

Berdasarkan latar belakang tersebut sering sekali terjadi masalah-masalah mengenai tanah di masyarakat. Sengketa hak milik atas tanah terjadi karena setiap manusia sangat membutuhkan tanah untuk melangsungkan kehidupannya,

sehinggamenyebabkanseseorangmenguasaihak atastanahmilik orang lain yang mana menguasai dan menempatitanahmilik orang lain adalahsuatuperbuatanmelawanhukum,

makakami penulis jurnal tertarik untuk melakukan penulisan jurnal denganjudul

"PerbuatanMelawan Hukum Menguasai

Hakatas Tanah Milik Orang Lain (Studi

Putusan Mahkamah Agung Nomor 3302 K/Pdt/2018)".

\section{B. RumusanMasalah}

1. Bagaimanaunsurunsurperbuatanmelawanhukum?

2. Bagaimanaakibathukum yang menguasaitanahhakmilik orang lain dalamPutusanMahkamah Agung Nomor 3302/K/Pdt/2018?

3. Bagaimanapertimbanganhukum hakim dalamPutusanMahkamah Agung Nomor $3302 \mathrm{~K} / \mathrm{Pdt} / 2018$ ?

\section{PEMBAHASAN}

A. Unsur-Unsur Perbuatan Melawan Hukum Terhadap Penguasaan Tanah Hak Milik Orang Lain

Perbuatan melawan hukum

berdasarkan Putusan Hoge Raad Nederlands pada tahun 1919 adalah: perbuatan melawan hukum merupakan suatu perbuatan yang melanggar hak orang lain atau jika orang berbuat bertentangan dengan kewajiban hukumnya.

Menurut Abdulkadir Muhammad dalam bukunya Hukum Perdata Indonesia mengatakan bahwa :

Konsep perbuatan melawan hukum (onrechtmatigedaad) dalam Pasal 1365 KUHPerdata yang sama rumusannya dengan Pasal 1401 BW Belanda yang menentukan sebagai berikut: setiap perbuatan melawan hukum yang mengakibatkan kerugian pada orang lain mewajibkan orang lain yang karena kesalahannya menimbulkan kerugian itu, menggantikan kerugian tersebut. ${ }^{6}$

Menurut Tajuddin Noor, et.al dalam Jurnalnya yang berjudul Tinjauan Yuridis Terhadap Perbuatan Melawan Hukum Atas Menempati/Menguasai Tanah Dan Bangunan Hak Orang Lain (Studi Kasus Putusan Nomor 340/PDT.G/2015/PN.MDN) mengatakan bahwa

Perbuatan melawan hukum adalah suatu bentuk perikatan yang lahir dari Undang-Undang sebagai akibat dari perbuatan manusia yang melanggar hukum, yang diatur dalam Kitab Undang-Undang Hukum perdata. Perbuatan melawan hukum itu sendiri dalam bahasa Belanda disebut dengan istilah "Onrechmatige daad" atau dalam bahasa Inggris disebut dengan istilah "tort". ${ }^{7}$

Berdasarkan rumusan tersebut dapat dipahami bahwa suatu perbuatan atau tindakan yang dikategorikan melawan hukum atau melangggar hukum harus melengkapi beberapa unsur-unsur yaitu :

a. Adanya suatu perbuatan;

${ }^{6}$ Abdulkadir Muhammad, Hukum Perdata Indonesia, PT Citra Aditya Bakti, Bandung, 2014, h.259.

${ }^{7}$ Tajuddin Noor, et al, TinjauanYuridisTerhadapPerbuatanMelawan Hukum Atas Menempati/Menguasai Tanah Dan BangunanHak Orang Lain (StudiKasusPutusanNomor

340/PDT.G/2015/PN.MDN), Fakultas Hukum Universitas Prima Indonesia, Vol.7 No.7, Maret 2019, h.129. 
Media Komunikasi dan Informasi Hukum dan Masyarakat

b. Perbuatan itu harus melawan hukum (onrechtmatig);

c. Perbuatan itu harus menimbulkan kerugian;

d. Perbuatan itu harus dilakukan dengan kesalahan; dan

e. Antara perbuatan dan kerugian yang timbul harus ada hubungan kausal.

Perbuatan menguasai tanah dan bangunan tanpa hak berdasarkan putusan Mahkamah Agung No. 3302 K/Pdt/2018 adalah perbuatan yang merugikan hak orang lain karena perbuatan Termohon Kasasi yang disebutkan dalam putusan tersebut yang tidak mau mengosongkan dan menyerahkan tanah dan bangunan objek perkara milik Pemohon Kasasi. Dengan perbuatan Termohon Kasasi tersebut hak Pemohon Kasasi untuk menikmati objek perkara yaitu pemilikan tanah dengan Sertifikat Hak Milik No. 27/Modayag atas nama Dortji Kapoh dan bangunan rumah diatasnya hilang sehingga menimbulkan kerugian bagi Pemohon Kasasi itu sendiri karenanya dengan patut dan wajar perbuatan Termohon Kasasi dapat dikategorikan sebagai perbuatan melawan hukum (onrechtmatigedaad).

Perbuatan malawan hukum yang dilakukan oleh Termohon Kasasi yang merugikan hak-hak Pemohon Kasasi berdasarkan unsur-unsur perbuatan melawan hukum tersebut dapat diberikan penjelasan sebagai berikut :

a. Adanya Suatu Perbuatan

Suatu perbuatan melawan hukum diawali oleh suatu perbuatan dari si pelakunya dalam hal ini adalah Termohon Kasasi yang menguasai tanah dan bangunan milik Pemohon Kasasi.

Munir Fuady dalam bukunya Perbuatan Melawan Hukum Mengatakan bahwa :
Suatu perbuatan melawan hukum tidak memiliki unsur persetujuan atau kata sepakat dan tidak ada juga unsur causal yang diperbolehkan sebagaimana yang terdapat dalam kontrak maksudnya terdapat anggapan bahwa adanya perbuatan bukan hanya perbuatan baik berbuat sesuatu (dalam arti aktif) maupun tidak berbuat sesuatu (dalam arti pasif), misalnya tidak berbuat sesuatu padahal dia mempunyai kewajiban hukum untuk membuatnya, kewajiban mana timbul dari hukum yang berlaku (karena ada juga kewajiban yang timbul dari suatu kontrak). ${ }^{8}$

b. Perbuatan Itu Harus Melawan Hukum (onrechtmatig).

Unsur ini, sebenarnya terdapat dua pengertian, yaitu perbuatan dan melawan hukum.

Keduanya saling berkaitan antara satu dengan yang lainnya. Keterkaitan ini dapat dibuktikan dengan dua cara, yaitu dengan cara penafsiran bahasa, melawan hukum menerangkan sifatnya dari perbuatan itu dengan kata lain melawan hukum merupakan kata sifat, sedangkan perbuatan merupakan kata kerja. Sehingga dengan adanya suatu perbuatan yang sifatnya melawan hukum, maka terciptalah kalimat yang menyatakan perbuatan melawan hukum. ${ }^{9}$

Pengertian perbuatan melawan hukum dalam arti sempit, hanya meliputi hak orang lain, dan kewajiban si pembuat yang bertentangan atau hanya melanggar hukum/Undang-Undang saja. Pendapat ini dikemukakan sebelum adanya Arrest Hoge Raad Tahun 1919. Sedangkan dalam arti luas, telah meliputi kesusilaan dan kepatutan yang berlaku dalam lalu lintas masyarakat terhadap diri dan barangbarang orang lain. Pendapat ini dikemukakan setelah pada waktu Arrest Hoge Raad Tahun 1919 digunakan.

Sejak tahun 1919, ada putusan Mahkamah Agung Belanda dalam kasus Arrest

8Munir Fuady, PerbuatanMelawan Hukum, PT Citra Aditya Bakti, Bandung, 2005, h.10-11.

${ }^{9}$ Abdulkadir Muhammad, Op.Cit, h.142. 
Media Komunikasi dan Informasi Hukum dan Masyarakat

Cohen-Lindenbaum (H.R. 31 Januari 1919), yang kemudian telah memperluas pengertian melawan hukum tidak hanya terbatas pada Undang-Undang (hukum tertulis saja) tapi juga hukum yang tidak tertulis, sebagai berikut :

a) Melanggar Undang-Undang, artinya perbuatan yang dilakukan jelas-jelas melanggar Undang-Undang;

b) Melanggar hak subjektif orang lain, artinya jika perbuatan yang dilakukan telah melanggar hak-hak orang lain yang dijamin oleh hukum (termasuk tapi tidak terbatas pada hak yang bersifat pribadi, kebebasan, hak kebendaan, kehormatan, nama baik ataupun hak perorangan lainnya);

c) Bertentangan dengan kewajiban hukum si pelaku, artinya kewajiban hukum baik yang tertulis maupun yang tidak tertulis, termasuk hukum publik;

d) Bertentangan dengan kesusilaan, yaitu kaidah moral (Pasal 1337 dan Pasal 1335 KUHPerdata);

e) Bertentangan dengan sikap kehatihatian yang sepatutnya dalam masyarakat. Kriteria ini bersumber pada hukum tak tertulis (bersifat relatif). Yaitu perbuatan yang dilakukan bertentangan dengan sikap yang baik/kepatutan dalam masyarakat untuk memperhatikan kepentingan orang lain.

Perbuatan yang dilakukan tersebut haruslah melawan hukum. Unsur melawan hukum ini diartikan dalam arti seluas-luasnya, yakni: perbuatanyang dilakukan adalah perbuatan yang melanggar Undang-Undang yang berlaku dan perbuatan yang dilakukan melanggar hak-hak orang lain yang dijamin oleh hukum maksudnya ialah Termohon Kasasi dalam hal ini melakukan perbuatan melawan hukum karena telah menguasai hak atas tanah milik orang lain secara melawan UndangUndang dan telah melanggar/mengambil hak dari Pemohon Kasasi untuk menguasai tanah miliknya yang telah dijamin oleh hukum.

Perbuatan melawan hukum secara melawan Undang-Undang disini dilakukan dengan melanggar Pasal 1335 dan Pasal 1337 KUHPerdata yang menyatakan bahwa suatu kausa dinyatakan terlarang jika bertentangan dengan Undang-Undang, kesusilaan dan ketertiban umum. Pasal 1335 dan 1337 KUHPerdata ini muncul dikarenakan adanya perjanjian dan tidak memenuhi syarat sahnya perjanjian yang ada pada Pasal 1320 KUHPerdata.

Syarat sahnya perjanjian disebutkan dalam Pasal 1320 KUHPerdata yaitu:

1. Kesepakatan mereka yang mengikat dirinya;

2. Kecakapan untuk membuat suatu perikatan;

3. Suatu pokok persoalan tertentu;

4. Suatu sebab yang tidak dilarang.

Syarat-syarat diatas terbagi dalam dua kelompok yaitu syarat subjektif (1) dan (2) dan syarat objektif (3) dan (4), dimana keduanya memiliki akibat hukum masing-masing, untuk lebih jelasnya penjelasan terhadap hal diatas adalah:

1) Sepakat mereka yang mengikatkan dirinya (Pasal 1321-1328 KUHPerdata)

Supaya perjanjian menjadi sah maka para pihak harus sepakat terhadap segala hal yang terdapat di dalam perjanjian dan memberikan persetujuannya atau kesepakatannya jika ia memang menghendaki apa yang disepakati. Setuju dan sepakat dilakukan dengan penuh kesadaran di antara 
Media Komunikasi dan Informasi Hukum dan Masyarakat

para pembuatnya, yang bisa diberikan secara lisan dan tertulis.

2) Kecakapan untuk membuat suatu perjanjian (Pasal 1329-1331 KUHPerdata)

Kecakapan adalah kemampuan untuk melakukan perbuatan hukum. Perbuatan hukum adalah perbuatan yang akan menimbulkan akibat hukum. Orang-orang yang akan mengadakan perjanjian haruslah orang-orang yang cakap dan wenang untuk melakukan perbuatan hukum sebagaimana yang ditentukan oleh Undang-Undang.

3) Suatu pokok hal tertentu (Pasal 1332-1334 KUHPerdata)

Suatu perjanjian harus mempunyai pokok suatu benda (zaak) yang paling sedikit dapat ditentukan jenisnya.suatu perjanjian harus mempunyai objek tertentu dan suatu perjanjian haruslah mengenai suatu hal tertentu, berarti bahwa apa yang diperjanjikan, yakni hak dan kewajiban kedua belah pihak.

4) Suatu sebab yang tidak dilarang (Pasal 1335-1337 KUHPerdata)

Suatu sebab adalah terlarang apabila bertentangan dengan Undang-Undang, kesusilaan dan ketertiban umum. Merupakan syarat terpenting juga bahwa perjanjian tidak boleh bertentangan dengan Undang-Undang, kebiasaan yang baik dan ketertiban umum yaitu

a) Pasal 1335 KUHPerdata : suatu perjanjian tanpa sebab atau yang telah dibuat karena suatu sebab yang palsu atau terlarang, tidak mempunyai kekuatan.

b) Pasal 1337 KUHPerdata : suatu sebab adalah terlarang, jika sebab itu dilarang oleh Undang-Undang atau bila sebab itu bertentangan dengan kesusilaan atau ketertiban umum.
Pada sengketa tanah ini penyerahan tanah tidak sesuai dengan hukum atau melawan hukum dan oleh karena syarat keempat sahnya perjanjian dalam Pasal 1320 KUHPerdata yaitu kausa yang halal atau suatu sebab yang tidak dilarang tidak dipenuhi, dalam arti isi Surat Penyataan Pisah Damai yang berisi penyerahan SHM dan bangunan diatasnya mengandung suatu sebab yang dilarang atau terlarang, hal ini sesuai dengan pengertian Pasal 1337 KUHPerdata yaitu: suatu sebab adalah terlarang, jika sebab itu dilarang oleh UndangUndang atau bila sebab itu bertentangan dengan kesusilaan atau dengan ketertiban umum.

Berdasarkan Pasal 1335 KUHPerdata penyerahan tanah yang ada di dalam Surat Pernyataan Pisah Damai dengan dasar adanya hal atau materi perjanjian yang bertentangan dengan Undang-Undang yang dianggap merugikan kepentingan Pemohon Kasasi dan menguntungkan Termohon Kasasi tidak mempunyai kekuatan hukum.

c. Perbuatan itu hanya dilakukan dengan kesalahan

Munir Fuady dalam bukunya yang berjudul Perbuatan Melawan Hukum mengatakan bahwa:

Suatu tindakan dianggap oleh hukum mengandung unsur kesalahan sehingga dapat dimintakan tanggung jawabnya secara hukum jika memenuhi unsur-unsur sebagai berikut :

1. Ada unsur kesengajaan; atau

2. Ada unsur kelalaian (negligence, culpa); dan

3. Tidak ada alasan pembenar atau alasan pemaaf (rechtvaardigingsgrond), seperti keadaan overmahct, membela diri, tidak waras, dan lain-lain. ${ }^{10}$

Kesalahan dalam uraian ini, ialah perbuatan yang disengaja atau lalai melakukan

${ }^{10}$ Munir Fuady, Op.Cit, h.12. 
Media Komunikasi dan Informasi Hukum dan Masyarakat

suatu perbuatan atau hanya perbuatan itu melawan hukum (onrechtmatigedaad).

Menurut hukum perdata, seseorang itu dikatakan bersalah jika terhadapnya dapat disesalkan bahwa ia telah melakukan/tidak melakukan sesuatu perbuatan yang seharusnya dihindarkan. Perbuatan yang seharusnya dilakukan/tidak dilakukan itu tidak terlepas dari pada dapat atau tidaknya hal-hal itu dikira-kira. Dapat dikira-kira itu harus diukur secara objektif, artinya manusia normal dapat mengira-ngirakan dalam keadaan tertentu perbuatan seharusnya dilakukan/tidak dilakukan. ${ }^{11}$

Perbuatan melawan hukum itu adalah perbuatan yang sengaja atau lalai melakukan suatu perbuatan. Kesalahan dalam unsur ini merupakan suatu perbuatan yang dapat dikirakira atau diperhitungkan oleh pikiran manusia yang normal sebagai tindakan yang dilakukan atau tidak dilakukannya perbuatan itu. Dengan demikian, melakukan atau tidak melakukan dapat dikategorikan ke dalam bentuk kesalahan.

Pendapat lain menyatakan bahwa kesalahan itu dapat terjadi, karena: disengaja dan tidak disengaja. Tentunya yang dimaksud dengan disengaja dan tidak disengaja dalam pernyataan diatas adalah dalam hal perbuatan. Disengaja dan tidak disengaja berarti kesalahan itu dapat terjadi dan dilakukan akibat dari suatu kelalaian.

Jika kelalaian dapat dianggap suatu unsur dari kesalahan, maka menurut pandangan hukum, kodrat manusia sebagai makhluk yang tidak pernah luput dari kesalahan dan kesilapan, merupakan suatu pedoman dasar di dalam menentukan bahwa perbuatan itu termasuk ke dalam suatu perbuatan yang melawan hukum dan tidak dapat dipungkiri lagi. Tetapi di dalam kenyataannya, kenapa masih banyak orang yang telah melakukan perbuatan melawan hukum, dapat menghindari dirinya dari tuduhan dan gugatan tersebut dalam arti mengingkari perbuatan melawan hukum yang ditunjukkan kepadanya.

Perbuatan yang memang disengaja, berarti sudah ada niat dari pelakunya atau si pembuat. Tetapi jika perbuatan itu tidak disengaja untuk dilakukan, dalam arti unsur kesilapan, suatu contoh dalam hal pembayaran harga barang dalam jual-beli tanah yang dilakukan si pembeli, apakah si pembeli dapat dikatakan telah melakukan perbuatan melawan hukum, menurut pendapat diatas. Atau seorang kasir pada suatu bank, yang silap melakukan perhitungan terhadap rekening si nasabah. Apakah perbuatan si kasir tersebut dapat dikatakan sebagai suatu kesalahan dan kepadanya dapat digugat Pasal 1365 KUHPerdata tersebut.

Dalam kasus ini perbuatan Termohon Kasasi menempati rumah yang bukan miliknya dilakukan dengan sengaja, karena Termohon Kasasi sudah tahu bahwa tanah hak milik dan bangunan diatasnya adalah milik orang tua dari Pemohon Kasasi tetapi Termohon Kasasi tetap saja menguasai tanah hak milik dan bangunan orang lain tanpa hak.

d. Perbuatan itu harus menimbulkan kerugian

Kerugian yang dimaksud di dalam unsur keempat ini, Undang-Undang tidak hanya menjelaskannya tentang ukurannya dan yang termasuk kerugian itu. Undang-Undang hanya menyebutkan sifat dari kerugian tersebut, yaitu materiil dan immateriil. "Kerugian ini dapat bersifat kerugian materiil dan kerugian immateriil, apa ukurannya, apa yang termasuk kerugian itu, tidak ada ditentukan lebih lanjut dalam Undang-Undang sehubungan dengan perbuatan melawan hukum". ${ }^{12}$ 
Media Komunikasi dan Informasi Hukum dan Masyarakat

Termasuk kerugian yang bersifat materiil dan immateriil ini adalah:

1) Materiil, maksudnya bersifat kebendaan (zakeljik). Contohnya: kerugian karena kerusakan tubrukan mobil, rusaknya rumah, hilangnya keuntungan, keluar ongkos barang dan sebagainya;

2) Immateriil, maksudnya bersifat tidak kebendaan. Contohnya: dirugikan nama baik seseorang, harga diri, hilangnya kepercayaan orang lain. ${ }^{13}$

Berdasarkan pernyataan di atas, apakah contoh-contoh tersebut telah memenuhi ukuran dari kerugian yang disebabkan oleh perbuatan melawan hukum. Hal ini dapat saja terjadi, karena Undang-Undang itu sendiri tidak ada mengaturnya. Namun demikian bukan berarti orang yang dirugikan tersebut dapat menuntut kerugian orang lain tersebut sesuka hatinya. Karena ada pendapat yang mengatakan:

Hoge Raad berulang-ulang telah memutuskan, bahwa kerugian yang timbul karena perbuatan melawan hukum, ketentuannya sama dengan ketentuan yang timbul karena wanprestasi dalam perjanjian (Pasal 1246-1248), walaupun ketentuan tersebut tidak dapat langsung diterapkan. Akan tetapi jika penerapan itu dilakukan secara analogis, masih dapat diperkenankan. ${ }^{14}$

kerugian (schade) bagi korban juga merupakan syarat agar gugatan berdasarkan Pasal 1365 KUHPerdata dapat dipergunakan. Dalam kasus ini yaitu Pemohon Kasasi dapat menerima ganti rugi dari Termohon Kasasi. Pada prakteknya dapat diterapkan ketentuan kerugian yang timbul karena wanprestasi dalam perjanjian. Walaupun penerapan ini hanya bersifat analogi. Namun tidak menutup kemungkinan terlaksananya penerapan ketentuan tersebut terhadap perbuatan

${ }^{13}$ MarhainisAbdulhay, Hukum Perdata, Pembinaan UPN, Jakarta, 2006, h.83.

${ }^{14} \mathrm{R}$. WirjonoProdjodikoro, Hukum

PerdataTentangPersetujuan-

PersetujuanTertentu, Sumur, Bandung, 2001, h.85. melawan hukum. Alasannya, karena tidak adanya pengaturan lebih lanjut dari UndangUndang tentang hal tersebut.

Kerugian yang dialami oleh Pemohon Kasasi dalam kasus ini yaitu kerugian dimana hilangnya hak-hak Pemohon Kasasi untuk dapat menguasai tanah miliknya sendiri secara bebas serta Pemohon Kasasi harus mengeluarkan uang untuk menyewa rumah lain untuk tempat tinggalnya padahal ia memiliki rumah.

e. Antara perbuatan dan kerugian ada hubungan kausal

Pasal 1365 KUHPerdata, hubungan kausal ini dapat terlihat dari kalimat perbuatan yang karena kesalahannya menimbulkan kerugian. Kerugian itu timbul disebabkan adanya perbuatan, atau kerugian itu merupakan akibat dari perbuatan. Hal yang menjadi masalah disini, apakah kerugian itu merupakan akibat perbuatan, sejauh manakah hal ini dapat dibuktikan kebenarannya. Jika antara kerugian dan perbuatan terdapat hubungan kausalitas (sebab akibat), maka sudah pasti dapat dikatakan bahwa setiap kerugian merupakan akibat dari suatu perbuatan.

Hubungan kausal antara perbuatan yang dilakukan dengan kerugian yang terjadi juga merupakan syarat dari suatu perbuatan melawan hukum. Didalam kasus putusan ini suatu perbuatan yang dilakukan oleh Temohon Kasasi adalah sebuah perbuatan yang menimbulkan kerugian bagi Pemohon Kasasi. Dan suatu pebuatan yang menimbulkan kerugian dapat dikatakan sebagai perbuatan melawan hukum.

Untuk hubungan sebab akibat ada 2 (dua) macam teori, yaitu teori hubungan faktual dan teori penyebab kira-kira. Hubungan sebab akibat secara faktual (causationin fact) hanyalah merupakan masalah "fakta" atau apa yang 
Media Komunikasi dan Informasi Hukum dan Masyarakat

secara faktual telah terjadi. Setiap penyebab yang menyebabkan timbulnya kerugian dapat merupakan penyebab secara faktual, asalkan kerugian (hasilnya) tidak akan pernah terdapat tanpa penyebabnya. Dalam hukum tentang perbuatan melawan hukum, sebab akibat jenis ini sering disebut dengan hukum mengenai "but for" atau "sine qua non".

Selanjutnya, agar lebih praktis dan agar tercapainya elemen kepastian hukum dan hukum yang lebih adil, maka diciptakanlah konsep "sebab kira-kira" (proximate cause). Proximate cause merupakan bagian yang paling membingungkan dan paling banyak pertentangan pendapat dalam hukum tentang perbuatan melawan hukum. Kadang-kadang, untuk penyebab jenis ini disebut juga dengan istilah legal cause atau dengan berbagai penyebutan lainnya.

\section{B. Akibat Hukum Menguasai Tanah Hak Milik Orang Lain dalam Putusan MA Nomor 3302 K/Pdt/2018}

Masalah tanah adalah masalah yang sangat aktual bagi manusia dimana saja, terutama masalah tanah dalam tanah hak milik dan bangunan diatasnya. "Sengketa perdata mengenai permasalahan pertanahan dapat diselesaikan melalui BPN (Badan Pertanahan Nasional) dan dapat juga melalui Pengadilan". ${ }^{15}$

Jika pemilik tanah dan bangunan diatasnya itu telah merasa dirugikan karena haknya telah diambil oleh orang lain maka pemilik tanah tersebut dapat mengajukan gugatan ke Pengadilan dengan dasar telah melanggar Pasal 1335 dan Pasal 1337

\footnotetext{
${ }^{15}$ Ali AchmadChomzah, Hukum Pertanahan Seri Hukum PertanahanIPemberianHak Atas Tanah Negara dan Seri Hukum Pertanahan II Sertifikat dan Permasalahannya, Prestasi Pustaka, Jakarta, 2002, h.31.
}

KUHPerdata yang mana dalam pasal tersebut adanya hal atau materi perjanjian yang bertentangan dengan Undang-Undang yang dianggap merugikan kepentingan Pemohon Kasasi dan menguntungkan Termohon Kasasi serta mengandung suatu sebab yang dilarang atau terlarang. Dan karena perbuatan tersebut telah menimbulkan kerugian maka terhadap kasus ini dapat dikenakan juga Pasal 1365 KUHPerdata. Perbuatan Termohon Kasasi tersebut telah memenuhi unsur-unsur perbuatan melawan hukum dalam Pasal 1365 KUHPerdata.

Sengketa pertanahan dalam kasus ini diselesaikan melalui sidang di Pengadilan. Yang mana Decky Posumah Kapoh sebagai Pemohon Kasasi mengajukan gugatan kepada Lenny Kanter sebagai Termohon Kasasi. Di dalam masalah ini Termohon Kasasi tidak mau memberikan tanah hak milik dari Pemohon Kasasi sebagai ahli waris yang sah dari kedua orang tuanya. Termohon Kasasi tetap ingin menguasai tanah hak milik tersebut beserta bangunan diatasnya sedangkan tanah hak milik tersebut atas nama Dortji Kapoh yaitu orangtua dari Decky Posumah Kapoh.

Awalnya Decky Posumah Kapoh mengajukan gugatan ke Pengadilan Negeri Kotamobagu dan Pengadilan Kotamobagu memenangkan Decky Posumah Kapoh sebagai penggugat karena Pengadilan Negeri berpendapat bahwa penguasaan tanah yang dilakukan oleh Lenny Kanter terhadap SHM Nomor 27 adalah tidak sah dan melawan hukum karena Lenny Kanter tidak mempunyai hak atas tanah tersebut.

Lenny Kanter tidak merasa puas dengan keputusan Pengadilan Negeri Kotamobagu maka Lenny Kanter mengajukan gugatan pada tingkat banding di Pengadilan 
Media Komunikasi dan Informasi Hukum dan Masyarakat

Tinggi Manado. Dalam tingkat banding Lenny Kanter memenangkan gugatannya karena Pengadilan Tinggi Manado berpendapat bahwa objek sengketa budel waris alm. Chung Ping Foe dan almh. Dortji Kapoh yang jatuh waris kepada 3 (tiga) orang anaknya yaitu : 1. Melky Sumakung, 2. Alm Indrato Cung, dan Decky Posumah Kapoh (Pemohon Kasasi) maka penyerahan objek sengketa oleh Pemohon Kasasi kepada Termohon Kasasi dengan Surat Pernyataan Pisah Damai tanggal 6 Mei 2010 tidak dapat dibenarkan karena objek sengketa bukan milik Pemohon Kasasi.

Setelah tingkat banding diputuskan maka Decky Posumah Kapoh merasa tidak puas dengan keputusan Pengadilan Tinggi Manado dan Decky Posumah Kapoh mengajukan perkara ini ke dalam tingkat Kasasi.

Majelis hakim tingkat kasasi memberi putusan bahwa Decky Posumah Kapohlah yang memenangkan perkara ini karena majelis hakim tingkat banding telah salah dalam menerapkan hukum. Maka Mahkamah Agung memutuskan untuk :

MENG A D I L I:

- Mengabulkan permohonan kasasi dari Pemohon Kasasi: DECKY POSUMAH $\mathrm{KAPOH}$ tersebut;

- Membatalkan Putusan Pengadilan Tinggi Manado Nomor 157/PDT/2017/PT MND. Tanggal 22 Februari 2018 yang membatalkan Putusan Pengadilan Negeri Kotamobagu Nomor 142/Pdt.G/2016/PN Ktg. tanggal 31 Mei 2017.

MENGADILI SENDIRI:

1. Mengabulkan gugatan Penggugat untuk sebagian;

2. Menyatakan bahwa Melly Sumakung, alm. Indrato Cung serta ahli waris penggantinya dan Decky Posumah Kapoh merupakan ahli waris yang sah dari alm. Chung Ping Foe dan almh. Dortji Kapoh;

3. Menyatakan bahwa Surat Pernyataan Pisah Damai tanggal 6 Mei 2010 dan perbuatan hukum penyerahan Sertifikat Tanah Hak Milik Nomor 27 atas nama Dortji Kapoh kepada Lenny Kanter dan 1 (satu) bangunan rumah atap seng dinding papan sebagian beton dan lantai beton batal demi hukum dan tidak mempunyai kekuatan hukum;

4. Menyatakan penguasaan Tergugat terhadap tanah objek sengketa dan Sertifikat Hak Milik Nomor 27/Modayag atas nama Dortji Kapoh tidak berdasar hukum, tidak sah, dan melawan hukum;

5. Menghukum Tergugat untuk menyerahkan asli Sertifikat Hak Milik Nomor 27/Modayag atas nama Dortji Kapoh kepada ahli waris yang sah dari alm. Chung Ping Foe dan almh. Dortji Kapoh;

6. Menghukum Tergugat atau siapa saja yang mendapat hak darinya untuk keluar dan mengosongkan tanah objek sengketa (SHM Nomor 27) tersebut untuk digunakan secara bebas oleh ahli waris yang sah dari alm. Chung Ping Foe dan almh. Dortji Kapoh jika perlu dengan bantuan aparat negara;

7. Menyatakan kepada Turut Tergugat untuk tunduk dan takluk pada putusan ini;

8. Menolak gugatan Penggugat selain dan selebihnya;

9. Menghukum Termohon Kasasi untuk membayar biaya perkara dalam semua tingkat peradilan, yang dalam tingkat Kasasi sebesar Rp. 500.000,00 (lima ratus ribu rupiah).

Akibat hukum dari dikeluarkannya putusan Mahkamah Agung Nomor 3302 
Media Komunikasi dan Informasi Hukum dan Masyarakat

K/Pdt/2018 yang berarti putusan ini menguatkan putusan Pengadilan Negeri Kotamobagu Nomor 142/Pdt.G/2016/PN.Ktg. maka terhadap Sertifikat Hak Milik Nomor 27 Modayag tersebut tetap menjadi hak milik dari Melly Sumakung, alm. Indrato Cung serta ahli waris penggantinya dan Decky Posumah Kapoh merupakan ahli waris yang sah dari alm. Chung Ping Foe dan almh. Dortji Kapoh.

Majelis hakim pada tingkat kasasi menyatakan penguasaan Termohon Kasasi terhadap tanah objek sengketa dan Sertifikat Hak Milik Nomor 27/Modayag atas nama Dorji Kapoh tidak berlandaskan hukum secara automatic, tidak sah, dan melawan hukum. Menghukum Termohon Kasasi untuk menyerahkan asli Sertifikat Hak Milik Nomor 27/Modayag atas nama Dortji Kapoh kepada ahli waris yang sah dari alm. Chung Ping Foe dan almh. Dortji Kapoh dan menghukum Termohon Kasasi atau siapa saja yang mendapat hak darinya untuk keluar dan mengosongkan tanah objek sengketa (SHM Nomor 27) tersebut untuk digunakan secara bebas oleh ahli waris yang sah dari almh. Chung Ping Foe dan almh. Dortji Kapoh. Dan Karena Termohon Kasasi berada di pihak yang kalah maka Termohon Kasasi dihukum untuk membayar semua tingkatan peradilan dari Pengadilan Negeri sampai kepada Pengadilan tingkat akhir yaitu Mahkamah Agung.

Dengan ini sudahlah jelas bahwa Lenny Kanter (Termohon Kasasi) harus mengosongkan tanah objek sengketa dan menyerahkan Sertifikat Hak Milik Nomor 27/Modayag tersebut kepada Decky Posumah Kapoh yang merupakan ahli waris yang sah dari almh. Dortji Kapoh. Apabila pihak Termohon Kasasi tidak berkenan mengosongkan tanah dan bangunan tersebut, maka Pemohon Kasasi dapat meminta bantuan dari aparat negara. Bahwa putusan dari tingkat kasasi ini adalah putusan yang mempunyai kekuatan hukum tetap (inkracht van gewijsde). Dengan telah dikeluarkannya putusan berkekuatan hukum tetap, maka para pihak diwajibkan untuk mematuhi dan melaksanakannya.

\section{Pertimbangan Hukum Hakim Dalam Putusan Mahkamah Agung Nomor 3302 K/Pdt/2018}

Pertimbangan hakim merupakan salah satu aspek terpenting dalam menentukan terwujudnya nilai dari suatu putusan hakim yang mengandung keadilan (ex aequo et bono) dan mengandung kepastian hukum, disamping itu juga mengandung manfaat bagi para pihak yang bersangkutan sehingga pertimbangan hakim ini harus disikapi dengan teliti, baik, dan cermat. "Apabila pertimbangan hakim tidak teliti, baik, dan cermat, maka putusan hakim yang berasal dari pertimbangan hakim tersebut akan dibatalkan oleh Pengadilan Tinggi/Mahkamah Agung". ${ }^{16}$

Kasus yang dianalisis yaitu Putusan Mahkamah Agung Nomor 3302 K/Pdt/2018 mengenai sengketa tanah. Latar belakang terjadinya kasus ini adalah ketika Decky Posumah Kapoh meminta tanah hak miliknya kepada Lenny Kanter sebagai mantan isterinya yang selama ini menguasai tanah hak milik dan bangunan diatasnya atas nama orang tua dari Decky Posumah Kapoh yaitu Dortji Kapoh. Tetapi Lenny Kanter tidak mau memberikan tanah hak milik yang telah ia kuasai tersebut. Sehingga menyebabkan Decky Posumah Kapoh

$$
{ }^{16} \text { Mukti }
$$
Arto, PraktekPerkaraPerdataPengadilan Agama, Cet V, Pustaka Pelajar, Yogyakarta, 2012, h.140. 
Media Komunikasi dan Informasi Hukum dan Masyarakat

mengajukan gugatan ke Pengadilan Negeri Kotamobagu.

Perbuatan yang dilakukan Lenny Kanter adalah suatu perbuatan yang dilakukan dengan sengaja yaitu menempati dan menguasai tanah hak milik orang lain. Penguasaan Lenny Kanter terhadap tanah Objek Sengketa dan Sertifikat Hak Milik Nomor 27/Modayag atas nama Dortji Kapoh tidak berlandaskan hukum secara automatic, tidak sah dan melawan hukum. Suatu perbuatan melawan hukum dikenakan Pasal 1365 KUHPerdata dikatanya suatu perbuatan melawan hukum adalah adanya tindakan atau kesalahan yang dilakukan seseorang dengan sengaja melakukan pelanggaran terhadap suatu ketentuan, sehingga adanya pelanggaran tersebut telah menimbulkan kerugian bagi orang lain dan mewajibkan orang karena perbuatannya untuk mengganti kerugian tersebut.

Pada sengketa pertanahan ini adanya perbuatan melawan hukum yang dilakukan oleh Termohon Kasasi sehingga menimbulkan hukum karena perbuatan yang dilakukan telah melanggar ketentuan dalam Pasal 1320 KUHPerdata yaitu kausa yang halal atau suatu sebab yang dilarang. Suatu sebab yang dilarang atau terlarang, sesuai dengan pengertian Pasal 1337 KUHPerdata yaitu suatu sebab adalah terlarang, jika sebab itu dilarang oleh UndangUndang atau bila sebab itu bertentangan dengan kesusilaan atau dengan ketertiban umum. Dan Pasal 1335 KUHPerdata yaitu adanya hal atau materi perjanjian yang bertentangan dengan Undang-Undang yang dianggap merugikan Pemohon Kasasi dan menguntungkan Termohon Kasasi.

Penyerahan Surat Pernyataan Pisah Damai yang berisi sertifikat hak milik Nomor 27/Modayag yang dilakukan oleh Pemohon
Kasasi kepada Termohon Kasasi dinyatakan batal demi hukum dan tidak mempunyai kekuatan hukum. Pada saat dilakukannya penyerahan tanah adanya suatu sebab yang terlarang yang dilakukan yang bertentangan dengan kesusilaan atau ketertiban umum maka penyerahan tanah tersebut dianggap telah merugikan Pemohon Kasasi. Perjanjian yang dilakukan telah bertentangan dengan hukum tertulis yang berlaku yaitu Undang-Undang Pokok Agraria Jo. Peraturan Pemerintah Nomor 24 Tahun 1997 Tentang Pendaftaran Tanah dan prinsip hukum pelaksanaan perjanjian formil harus dalam bentuk sebuah akta.

\section{Posisi Kasus}

1. Indentitas Para Pihak

i. DECKY POSUMAH KAPOH, bertempat tinggal di Desa Tobongon, Kecamatan Modayag, Kabupaten Bolaang Mongondow Timur, sebagai Pemohon Kasasi;

ii. LENNY KANTER, bertempat tinggal di Jalan Kartini (Toko Senyum Manis), Kota Kotamobagu, sebagai Termohon Kasasi;

iii. BADAN PERTANAHAN NASIONAL PUSAT di Jakarta c.q. KANTOR WILAYAH BADAN PERTANAAN NASIONAL PROPINSI SULAWESI UTARA c.q. BADAN PERTANAHAN NASIONAL KABUPATEN BOLAANG MONGONDOW, sebagai Turut Termohon Kasasi.

\section{Ringkasan Kasus}

Bahwa awal mula penyebab munculnya sengketa adalah karena Termohon Kasasi yang dahulu sebagai tergugat pernah menikah dengan Pemohon Kasasi yang dahulu sebagai penggugat. Kemudian karena ketidakcocokan 
Media Komunikasi dan Informasi Hukum dan Masyarakat

antara keduanya maka mereka becerai dan perceraian mereka sudah diputus dengan putusan Pengadilan Negeri Kotamobagu tanggal 17 Desember 2015 No. 114/Pdt.G.2015/P.Ktg. Dengan berpisahnya mereka sebagai suami isteri maka tidaklah ada lagi hubungan diantara keduanya.

Termohon Kasasi yang dahulu tinggal satu rumah dengan Pemohon Kasasi tidak mau menyerahkan tanah dan bangunan diatasnnya. Termohon Kasasi malah ingin menguasai tanah hak milik tersebut karena tanah tersebut berada dalam penguasaannya selama ini. Tanah objek sengketa tersebut bisa dikuasai oleh Termohon Kasasi karena dahulu sebelum adanya putusan Pengadilan Nomor 114/Pdt.G/2015/P.Ktg. pada tahun 2010 mereka berpisah secara damai dan Pemohon Kasasi mengatakan akan memberikan tanah objek sengketa dan bangunan diatasnya kepada Termohon Kasasi.

Penyerahan sertifikat yang merupakan akta otentik dan bangunan diatasnya oleh Pemohon Kasasi kepada Termohon Kasasi saat penandatanganan Surat Pernyataan Pisah Damai 6 Mei 2010 tidak dibuatkan akta hibah (akta otentik) di hadapan Pejabat Pembuat Akta Tanah (PPAT) sehingga penyerahan sertifikat tersebut tidak sesuai dengan hukum atau melawan hukum karena tidak memenuhi syarat keempat suatu perjanjian dalam Pasal 1320 KUHPerdata yaitu kausa yang halal dan suatu sebab dilarang atau terlarang.

Suatu sebab yang dilarang atau terlarang terdapat dalam Pasal 1337 KUHPerdata yaitu suatu sebab adalah terlarang jika sebab itu dilarang oleh Undang-Undang atau bila sebab itu bertentangan dengan kesusilaan atau dengan ketertiban umum. Oleh sebab itu Surat Pernyataan Pisah Damai tanggal 6 Mei 2010 yang berisi penyerahan sertifikat tanah Nomor 27 atas nama Dortji Kapoh tersebut batal demi hukum dan tidak mempunyai kekuatan hukum yang tetap. Serta dikenakan Pasal 1335 KUHPerdata dengan dasar adanya hal atau materi perjanjian yang bertentangan dengan Undang-Undang yang dianggap merugikan kepentingan Pemohon Kasasi dan menguntungkan Termohon Kasasi.

Tanah tersebut berada di Desa Tobongan, Kecamatan Modayag Kabupaten Bolaang Mongondow Timur. Setelah Dortji Kapoh meninggal dunia maka sebidang tanah dan bangunan diatasnya itu jatuh pada anakanak dari Dortji Kapoh sebagai ahli waris.

Sebidang tanah dan bangunan diatasnya tersebut telah diterbitkan Sertifikat Hak Milik Nomor 27 atas nama Dortji Kapoh. Bahwa Dortji Kapoh memiliki 3 anak yaitu : 1. Melky Sumakung, 2. Alm. Indrato Cung, dan 3. Decky Posumah Kapoh. Atas kesepakatan bersama antara mereka kakak beradik, tanah dengan SHM Nomor 27 atas nama Dortji Kapoh tersebut menjadi milik Decky Posumah Kapoh (Pemohon Kasasi). Karena penyerahan sertifikat itu dikatakan batal demi hukum maka Termohon Kasasi tidak memiliki hak atas tanah tersebut, tetapi Termohon Kasasi tidak mau menyerahkan tanah tersebut kepada Pemohon Kasasi sebagai ahli waris yang sah dari orang tuanya. Dikarenakan Termohon Kasasi tetap ingin menguasai tanah tersebut dan tidak ingin memberikan tanah tersebut kepada Pemohon Kasasi maka dengan itu Pemohon Kasasi mengajukan gugatan ke Pengadilan Negeri.

$$
\text { Pemohon Kasasi mengajukan }
$$

gugatannya ke Pengadilan Negeri Kotamobagu pada tanggal 27 Desember 2016 dengan harapan mendapatkan keadilan. Pada Pengadilan Negeri Pemohon Kasasi yang dahulu penggugat menang dalam gugatannya. 
Media Komunikasi dan Informasi Hukum dan Masyarakat

Kemudian Termohon Kasasi yang dahulu tergugat tidak menerima kemenangan dari Pemohon Kasasi maka Termohon Kasasi menggugat ke Pengadilan Tinggi Manado. Termohon Kasasi yang dahulu tergugat di Pengadilan Tinggi ini menjadi Pembanding. Pembanding dalam Pengadilan Tinggi Manado memenangkan gugatannya dan Pengadilan Tinggi Manado membatalkan putusan Pengadilan Negeri Kotamobagu. Setelah keluarnya putusan dari Pengadilan Tinggi Manado diberitahukan kepada Pemohon Kasasi. Kemudian Pemohon Kasasi tidak menerima kemenangan dari Termohon Kasasi maka Pemohon Kasasi mengajukan gugatan ke Mahkamah Agung.

Pemohon Kasasi tetap menuntut haknya terhadap tanah tersebut dan sebagai ahli waris yang sah dari orang tuanya untuk mendapatkan tanah hak milik tersebut. Pemohon Kasasi pun mengajukan memori kasasi kepada Mahkamah Agung. Setelah mengajukan memori kasasi ke Mahkamah Agung maka Mahkamah Agung memutuskan untuk membatalkan putusan Pengadilan Tinggi Manado Nomor 157/PDT/2017/PT MND tersebut dan mengabulkan gugatan Pemohon Kasasi dahulu sebagai penggugat. Mahkamah Agung juga menguatkan Putusan Pengadilan Negeri Kotambagu Nomor 142/Pdt.G/2016/PN Ktg.

Mahkamah Agung membatalkan
putusan Pengadilan Tinggi Manado karena
setelah meneliti memori kasasi dengan pertimbangan Judex Facti/Pengadilan Tinggi Manado dapat dikatakan bahwa keputusan Pengadilan Tinggi Manado yang membatalkan putusan Pengadilan Negeri Kotamobagu adalah salah karena Pengadilan Tinggi Manado telah salah dalam menerapkan hukum.
3. Pertimbangan Hukum Hakim

Menimbang,bahwaberdasarkansuratsuratyang bersangkutan, Penggugat dalam gugatannya memohonkepada

PengadilanKotamobagu

untukmemberikanputusansebagaiberikut:

1. MengabulkangugatanPenggugatuntukselur uhnya;

2. Menyatakan bahwa Melly Sumakung, alm. Indrato Cung dan Decky PosumahKapohadalahsebagaiahliwarisyan gsahdarialm.Chung PingFoedanalmh.DortjiKapoh;

3. MenyatakanpenguasaanTergugatterhadapt anahobjeksengketayakni

SHMNomor27adalahtidaksahdanmelawanh ukum;

4. Menghukum Tergugat untuk menyerahkanasli SHMNomor 27 atas namaDortjiKapohkepadaPenggugat;

5. Menghukum tergugat atau siapa saja yang mendapat hak darinya untuk keluar dan mengosongkan tanah objek sengketa (SHM Nomor 27) tersebut untuk digunakan secara bebas oleh Penggugat jika perlu dengan bantuan aparat negara;

6. Menyatakan kepada Turut Tergugat untuk tunduk dan takluk pada putusan ini;

7. Menyatakan putusan dapat dijalankan terlebih dahulu walaupun ada verzet, banding, kasasi ataupun upaya hukum lainnya;

8. Biaya perkara menurut hukum;

9. Mohon Keadilan;

Menimbang, bahwa terhadap gugatan tersebut Pengadilan Negeri Kotamobagu telah memberikan Putusan Nomor 142/Pdt.G/2016/PN Ktg. tanggal 31 Mei 2017, yang amarnya sebagai berikut: 
Media Komunikasi dan Informasi Hukum dan Masyarakat

1. Mengabulkan gugatan Penggugat untuk sebagian;

2. Menyatakan bahwa Melly Sumakung, alm. Indrato Cung serta ahli waris penggantinya dan Decky Posumah Kapoh merupakan ahli waris yang sah dari alm. Chung Ping Foe dan almh. Dortji Kapoh;

3. Menyatakan bahwa Surat Pernyataan Pisah Damai tanggal 6 Mei 2010 dan perbuatan hukum penyerahan Sertifikat Tanah Hak Milik Nomor 27 atas nama Dortji Kapoh kepada Lenny Kanter dan 1 (satu) bangunan rumah atap seng dinding papan sebagian beton dan lantai beton batal demi hukum dan tidak mempunyai kekuatan hukum;

4. Menyatakan penguasaan Tergugat terhadap tanah objek sengketa dan Sertifikat Hak Milik Nomor 27/Modayag atas nama Dortji Kapoh tidak berdasar hukum, tidak sah, dan melawan hukum;

5. Menghukum Tergugat untuk menyerahkan asli Sertifikat Hak Milik Nomor 27/Modayag atas nama Dortji Kapoh kepada ahli waris yang sah dari alm. Chung Ping Foe dan almh. Dortji Kapoh;

6. Menghukum Tergugat atau siapa saja yang mendapat hak darinya untuk keluar dan mengosongkan tanah objek sengketa (SHM Nomor 27) tersebut untuk digunakan secara bebas oleh ahli waris yang sah dari alm. Chung Ping Foe dan almh. Dortji Kapoh jika perlu dengan bantuan aparat negara;

7. Menyatakan kepada turut Tergugat untuk tunduk dan takluk pada putusan ini;

8. Membebankan ongkos perkara kepada tergugat sebesar Rp. 2.276.000.00- (dua juta dua ratus tujuh puluh enam ribu rupiah);
9. Menolak gugatan Penggugat selain dan selebihnya;

Kemudian putusan tersebut dibatalkan oleh Pengadilan Tinggi Manado dengan Putusan Nomor 157/PDT/2017/PT MND. tanggal 22 Februari 2018 dengan amar selengkapnya sebagai berikut:

- Menerima permohonan banding dari Tergugat/Pembanding;

- Membatalkan Putusan Pengadilan Negeri Kotamobagu Nomor 142/Pdt.G/2016/PN Ktg. tanggal 31 Mei 2017;

Mengadili Sendiri:

- Menolak gugatan Penggugat/Terbanding seluruhnya;

- Menghukum Terbanding semula Penguggat untuk membayar biaya perkara pada kedua tingkat peradilan, yang dalam tingkat banding sebesar Rp150.000,00 (seratus lima puluh ribu rupiah);

Menimbang, bahwa sesudah putusan terakhir ini diberitahukan kepada Pemohon Kasasi pada tanggal 29 Maret 2018 kemudian terhadapnya oleh Pemohon Kasasi diajukan permohonan kasasi pada tanggal 11 April 2018 sebagaimana ternyata dari Akta Pernyataan Permohonan Kasasi Nomor 142/Pdt.G/2016/PN Ktg. yang dibuat oleh Panitera Pengadilan Negeri Kotamobagu, permohonan tersebut diikuti dengan memori kasasi yang memuat alasan-alasan yang diterima di kepaniteraan Pengadilan Negeri tersebut pada tanggal 24 April 2018;

Menimbang, bahwa permohonan kasasi a quo beserta alasan- alasannya telah diberitahukan kepada pihak lawan dengan saksama, diajukan dalam tenggang waktu dan dengan cara yang ditentukan dalam UndangUndang, oleh karena itu permohonan kasasi tersebut secara formal dapat diterima; 
Media Komunikasi dan Informasi Hukum dan Masyarakat

Menimbang, bahwa berdasarkan memori kasasi yang diterima tanggal 24 April 2018 yang merupakan bagian tidak terpisahkan dari putusan ini, Pemohon Kasasi meminta agar:

- Menerima permohonan kasasi dan Pemohon Kasasi semula

Terbanding/Penggugat;

- Membatalkan Putusan Pengadilan Tinggi Manado Nomor 157/PDT/2017/PT MND. tanggal 22 Februari 2018;

Dengan Mengadili Sendiri

- Mengabulkan gugatan Penggugat;

- Menguatkan Putusan Pengadilan Negeri Kotamobagu Nomor 142/Pdt.G/2016/PN Ktg. tanggal 31 Mei 2017;

- Menghukum Tergugat sekarang Termohon Kasasi/Pembanding untuk membayar biaya perkara pada semua tingkat peradilan;

Menimbang, bahwa setelah meneliti memori kasasi yang diterima tanggal 24 April 2018 dihubungkan dengan pertimbangan Judex Facti/Pengadilan Tinggi Manado, Mahkamah Agung berpendapat sebagai berikut:

Bahwa alasan-alasan tersebut dapat dibenarkan oleh karena judex facti dalam hal ini Pengadilan Tinggi Manado yang membatalkan Putusan Pengadilan Negeri Kotamobagu telah salah menerapkan hukum dengan pertimbangan sebagai berikut:

Bahwa objek sengketa budel waris alm. Chung Ping Foe dan almh. Dortji Kapoh yang jatuh waris kepada 3 (tiga) orang anaknya yaitu: 1. Melky Sumakung, 2. Alm. Indrato Cung, 3. Decky Posumah Kapoh i.c. Penggugat, maka penyerahan objek sengketa oleh Penggugat kepada Tergugat dengan Surat Pernyataan Pisah Damai tanggal 6 Mei 2010 tidak dapat dibenarkan karena objek sengketa bukan milik Penggugat;

Bahwa oleh karena itu putusan Judex Facti/Pengadilan Tinggi Manado harus dibatalkan dan Mahkamah Agung akan mengadili sendiri perkara ini;

Menimbang, bahwa berdasarkan pertimbangan di atas, terdapat cukup alasan untuk mengabulkan permohonan kasasi dari Pemohon Kasasi DECKY POSUMAH KAPOH dan membatalkan Putusan Pengadilan Tinggi Manado Nomor 157/PDT/2017/PT MND. tanggal 22 Februari 2018 yang membatalkan Putusan Pengadilan Negeri Kotamobagu Nomor 142/Pdt.G/2016/PN Ktg. tanggal 31 Mei 2017 serta Mahkamah Agung mengadili sendiri perkara ini dengan amar putusan sebagaimana yang akan disebutkan di bawah ini;

Menimbang, bahwa oleh karena Termohon Kasasi berada di pihak yang kalah, maka dihukum untuk membayar biaya perkara dalam semua tingkat peradilan;

Memperhatikan Undang-Undang Nomor 48 Tahun 2009 tentang Kekuasaan Kehakiman, Undang-Undang Nomor 14 Tahun 1985 tentang Mahkamah Agung sebagaimana telah diubah dengan Undang-Undang Nomor 5 Tahun 2004 dan perubahan kedua dengan Undang-Undang Nomor 3 Tahun 2009 serta peraturan perundangan lain yang bersangkutan.

MENG A D I L I:

- Mengabulkan permohonan kasasi dari Pemohon Kasasi: DECKY POSUMAH $\mathrm{KAPOH}$ tersebut;

Membatalkan Putusan Pengadilan Tinggi Manado Nomor 157/PDT/2017/PT MND. Tanggal 22 Februari 2018 yang membatalkan Putusan Pengadilan Negeri Kotamobagu Nomor 142/Pdt.G/2016/PN Ktg. tanggal 31 Mei 2017. 
Media Komunikasi dan Informasi Hukum dan Masyarakat

MENGADILI SENDIRI:

1. Mengabulkan gugatan Penggugat untuk sebagian;

2. Menyatakan bahwa Melly Sumakung, alm. Indrato Cung serta ahli waris penggantinya dan Decky Posumah Kapoh merupakan ahli waris yang sah dari alm. Chung Ping Foe dan almh. Dortji Kapoh;

3. Menyatakan bahwa Surat Pernyataan Pisah Damai tanggal 6 Mei 2010 dan perbuatan hukum penyerahan Sertifikat Tanah Hak Milik Nomor 27 atas nama Dortji Kapoh kepada Lenny Kanter dan 1 (satu) bangunan rumah atap seng dinding papan sebagian beton dan lantai beton batal demi hukum dan tidak mempunyai kekuatan hukum;

4. Menyatakan penguasaan Tergugat terhadap tanah objek sengketa dan Sertifikat Hak Milik Nomor 27/Modayag atas nama Dortji Kapoh tidak berdasar hukum, tidak sah, dan melawan hukum;

5. Menghukum Tergugat untuk menyerahkan asli Sertifikat Hak Milik Nomor 27/Modayag atas nama Dortji Kapoh kepada ahli waris yang sah dari alm. Chung Ping Foe dan almh. Dortji Kapoh;

6. Menghukum Tergugat atau siapa saja yang mendapat hak darinya untuk keluar dan mengosongkan tanah objek sengketa (SHM Nomor 27) tersebut untuk digunakan secara bebas oleh ahli waris yang sah dari alm. Chung Ping Foe dan almh. Dortji Kapoh jika perlu dengan bantuan aparat negara;

7. Menyatakan kepada Turut Tergugat untuk tunduk dan takluk pada putusan ini;

8. Menolak gugatan Penggugat selain dan selebihnya;
9. Menghukum Termohon Kasasi untuk membayar biaya perkara dalam semua tingkat peradilan, yang dalam tingkat Kasasi sebesar Rp 500.000,00 (lima ratus ribu rupiah).

\section{Analisis Putusan}

Berdasarkan analisis saya dalam kasus sengketa tanah ini, bahwa tanah objek sengketa tersebut adalah milik orangtua dari Pemohon Kasasi yaitu Dortji Kapoh. Tanah dan bangunan diatasnya tersebut berkedudukan di Desa Tobongan Kecamatan Modayag Kabupaten Bolaang Mongondow Timur dan sudah bersetifikat dengan SHM Nomor 27 atas nama Dortji Kapoh. Setelah adanya kesepakatan bersama antara kakak beradik sebagai ahli waris yang sah maka tanah tersebut jatuh pada Decky Posumah Kapoh (Pemohon Kasasi).

Dengan demikian sudahlah jelas bahwa Pemohon Kasasi mempunyai hak kepemilikan tanah yang kuat atas tanah objek perkara tersebut. Termohon Kasasi hanyalah sebagai mantan isteri dari Pemohon Kasasi yaitu Decky Posumah Kapoh dan tidak mempunyai hak atas tanah tersebut karena mereka sudah berpisah dan tidak memiliki hubungan lagi. Adanya pernyerahan sertifikat tanah oleh Pemohon Kasasi kepada Termohon Kasasi sudah dinyatakan batal demi hukum oleh Pengadilan dan tidak mempunyai kekuatan hukum. Sehingga Termohon Kasasi tidak mempunyai hak untuk tetap tinggal diatas tanah objek sengketa tersebut.

Perbuatan yang dilakukan oleh Termohon Kasasi adalah perbuatan melawan hukum karena kesalahan Termohon Kasasi menimbulkan kerugian bagi orang lain. Dikarenakan pada saat penyerahan SHM yang dimasukkan kedalam Surat Pernyataan Pisah 
Media Komunikasi dan Informasi Hukum dan Masyarakat

Damai telah melanggar ketentuan dalam Pasal 1335 dan 1337 KUHPerdata yaitu adanya suatu sebab terlarang dalam penyerahannya. Perbuatan yang dilakukan Termohon Kasasi tersebut karena telah melanggar kausa yang halal pada Pasal 1320 KUHPerdata maka Termohon Kasasi dapat dikenakan Pasal 1365 KUHPerdata yaitu perbuatan melawan hukum dengan telah melanggar peraturan perundangundangan karena menempati dan menguasai suatu objek tanah yang bukan hak miliknya melainkan hak orang lain.

Perbuatan yang bertentangan dengan hak orang lain (inbreuk op eens anders recht) termasuk salah satu perbuatan yang dilarang oleh Pasal 1365 KUHPerdata. Hak-hak yang dilanggar tersebut adalah hak-hak seseorang yang diakui oleh hukum, termasuk tetapi tidak terbatas pada hak-hak sebagai berikut:

1. Hak-hak pribadi (persoonlijkheidsrechten);

2. Hak-hak kekayaan (vermogensrecht);

3. Hak atas kebebasan;

4. Hak atas kehormatan dan nama baik.

Sertifikat Hak Milik No. 27 atas nama Dortji Kapoh telah dikeluarkan oleh Badan Pertanahan Pusat di Jakarta C.q. Kantor Wilayah Badan Pertanahan Nasional Propinsi Sulawesi Utara C.q. Badan Pertanahan Nasional Kabupaten Bolaang Mongondow merupakan dasar dan dalil bukti Pemohon Kasasi untuk membuktikan bahwa hak Pemohon Kasasi telah dilanggar oleh Termohon Kasasi.

Pada putusan Mahkamah Agung, sebelum hakim Mahkamah Agung memutus, hakim Mahkamah Agung juga melihat pertimbanganpertimbangan pada putusan Pengadilan Negeri Kotamobagu dan pertimbangan-pertimbangan pada putusan Pengadilan Tinggi Manado. Mahkamah Agung akan melihat apakah ada kesalahan dalam penerapan hukum antara Pengadilan tingkat pertama dan tingkat banding.

Penulis sepakat dengan pertimbangan dan putusan majelis hakim yang menyatakan bahwa Termohon Kasasi dalam penguasaannya terhadap tanah hak milik orang lain yang sudah memiliki sertifikat dengan Sertifikat Hak Milik Nomor 27/Modayag adalah tidak berlandaskan hukum secara automatic, tidak sah dan melawan hukum, sehingga Termohon Kasasi haruslah menyerahkan asli Sertifikat Hak Milik No. 27/Modayag tersebut kepada ahli waris yang sah dari alm. Chung Ping Foe dan almh. Dortji Kapoh serta Termohon Kasasi haruslah mengosongkan/meninggalkan tanah dan bangunan diatasnya tersebut untuk dapat digunakan secara bebas oleh Pemohon Kasasi. 